Bangladesh J. Zool. 39(2): 147-156, 2011

\title{
OCCURRENCE OF GIARDIA IN THE EFFLUENTS OF A WASTE WATER TREATMENT PLANT IN DHAKA
}

\author{
Hamida Khanum*, Sharmili Shanjida Khanam, Masuma Sultana, \\ Md. Hafiz Uddin, Ripon Chandra Dhar and Md. Sirazul Islam ${ }^{1}$ \\ Department of Zoology, University of Dhaka, Dhaka-1000, Bangladesh
}

\begin{abstract}
The present study was designed for the qualitative and quantitative detection of Giardia in the Pagla Sewage Treatment Plant (PSTP) in Dhaka. The physico-chemical parameters of the sewage water were also recorded. Total 72 raw and treated samples were collected from PSTP throughout the year 2008 and these were processed with the Formol-Ether Concentration method and IMS followed by microscopy to identify Giardia in the sewage water. The protozoan parasite Giardia was abundant $\left(2.23 \pm 1.44 \times 10^{5} \mathrm{cyst} / 1\right)$ in the sewage water dominating the sampling sites-Grit chamber (44\%), Measuring chamber $(34 \%)$ and Outlet lagoon (38\%). A low abundance of Giardia in the PSTP starting from the first point to the last one indicates the waste water treatment efficiency for removal of the pathogen. A significant correlation was found for log (number of Giardia +1$)$ with turbidity $(\mathrm{r}=0.729)$ and TDS $(\mathrm{r}=0.536)$ at 0.01level.

mu - msł

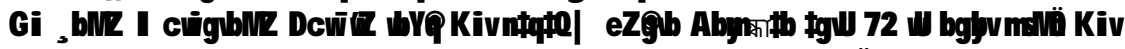

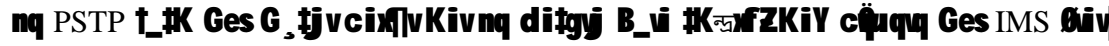

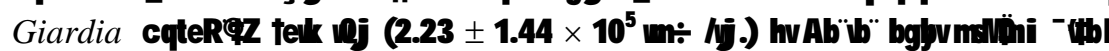

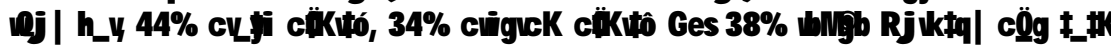

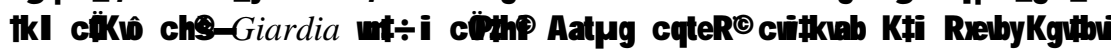

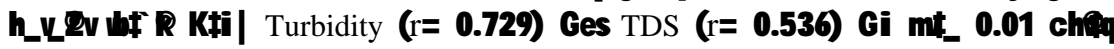

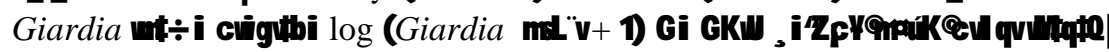

Key words: Giardiasis, Formol-Ether Concentration Method, IMS, Abundance, Correlation, Turbidity, TDS.
\end{abstract}

\section{INTRODUCTION}

Waterborne parasitic infections are common worldwide due to the shortage of drinking water, and unhygienic conditions of storage and manipulation of contaminated water in different daily purposes (WHO 1991). At least 325 reported water related outbreaks of protozoan parasites worldwide where Cryptospordium and Giardia have been reported to account for a majority of these outbreaks affecting millions of people ( Karanis et al. 2007).

About 200 million people have symptomatic Giardiasis worldwide, with prevalences of $2-5 \%$ in industrialized countries and $20-30 \%$ in developing regions of Asia, Africa and Latin America (Carmena 2010). Transmission of

*Corresponding author: E-mail: hamida_khanum@yahoo.com>. ${ }^{1}$ Environmental Microbiology Laboratory, Laboratory Sciences Division, International Centre for Diarrhoeal Disease Research, Bangladesh, G.P.O. Box 128, Dhaka 1000, Bangladesh. 
Giardia occurs by faecal-oral route of exposure and is sustained by zoonotic and anthroponotic cycles where several species and genotypes are enrolled (Almeida et al. 2010). Besides adults, children are highly susceptible whereas breast-fed infants (less than 6 months of age) are not likely to be infected (EPA 1998). The infected hosts shed a large number of transmissive and infective cysts in the environment, contributing to an increase of environmental contamination, in particular water courses. The cysts remain infective for long periods in natural environment, resistant to the conventional water treatment processes and small infectious dose, representing a serious problem of public health (Nikaeen et al. 2003).

Increased human consumption and pollution have caused a shortage of fresh water resources worldwide forced to use of recycled waste water with a low level of physico-chemical and biological contaminants (virus, bacteria and other parasites) is a common practice because absolute purification of waste water is not always possible but some type of recycling plants can be considered to reduce the contaminations (Caccio et al. 2003, Parvez et al. 2007). The occurrence of Giardia in the sewage treatment plants varies due to the differences in the standard and treatment technology in the respective sewage treatment plant (Roach et al. 1993, Wallis et al. 1995, Amahmid et al. 2002, Farias et al. 2002, Scott et al. 2003). Giardia cysts more readily (40\%-100\%) penetrate through conventional waste water treatment processes depending upon the degree of treatment (Sykora et al. 1987). Sewage treatment plants have the potential to become a source of contamination if malfunctions or inadequately treat the effluents before discharging into nearby water body.

To check the efficiency of any treatment plant most frequently used system is biological or physic-chemical indicator alone or simultaneously. Public health is not adequately protected by simply monitoring schemes based on detection of a single indicator. It is necessary to have a look on both physico-chemical and biological indicators simultaneously. Different organisms such as algae, fish, microorganisms and parasites are frequently used as biological indicators. According to the literature, to evaluate the system performance an inexpensive method is the microscopic observation of different protozoal species, combined with personal judgement of evaluators (Luna-Pabello et al.1990). Physicochemical parameters such as temperature, $\mathrm{pH}$, Total Dissolved Solids (TDS), conductivity and Total Suspended Solids (TSS) are generally used for evaluating effluent quality. These criteria are important for monitoring and controlling contaminations of recycled effluents repeatedly emphasized (Parvez et al. 2007). The efficiency of sewage treatment plants to reducing the concentration of Giardia cysts along with physico-chemical parameters has not been evaluated in 
Bangladesh so far. Probably unavailability of satisfactory methodology for concentrating and detecting Giardia in wastewater samples is responsible. Recent studies included microscopic evaluation coupled with IMS (Immunomagnetic Separation).

Domestic and industrial wastes of Dhaka city primarily discharged into the river Buriganga by different pathways where Pagla Sewage Treatment Plant (PSTP) outfall is one of them that utilizes waste stabilization method, operated by Dhaka Water Supply and Sewerage Authority (DWASA) situated in the eastern part of Dhaka, Bangladesh. The PSTP covers about $18 \%$ of the city population. The capacity of this treatment plant is only 0.12 million $\mathrm{m}^{3} /$ day while the total sewage generated by the people of Dhaka city as estimated by DWASA is about 1.3 million $\mathrm{m}^{3} /$ day (Hasan et al. 2006). No previous record concerning sewage treatment plant with parasites and physico-chemical parameters was found; hence the present study is very significant to assess the health hazard of the people of Dhaka city. The qualitative and quantitative detection of Giardia for assessing physico-chemical parameters will provide key informations for water utilities and improve water resource management for environmental health protection. Besides, the detection of Giardia in waste water may provide important clues for the environmental epidemiology of the parasites in this region.

\section{OBJECTIVES}

The present study was aimed to monitor treatment efficiency of the effluents of Pagla Sewage Treatment Plant using selected novel and classical physicchemical and biological indicators. The qualitative and quantitative detection of Giardia for assessing physico-chemical parameters were also studied.

\section{MATERIAL AND METHODS}

In the Pagla Sewage Treatment Project (PSTP) in Dhaka, 72 effluent samples were collected fortnightly in 24 successful rounds. The samples were collected from three separate points- raw sample from Grit Chamber, reservoir sample from Measuring Chamber and treated sample from Outlet Lagoon of the PSTP. From each sampling site $2 \mathrm{~L}$ effluent samples were collected from $13^{\text {th }}$ February to $3^{\text {rd }}$ March 2008. All the samples were immediately transferred to the laboratory for parasitological examination and detection of chemical parameters.

Parasitological examination: Samples were processed by Formol-Ether Concentration Method following a light microscopy to observe the parasites. Due to minute size, attachment to particulate matter in the sample and relatively few in number in external environment make Giardia cysts very difficult to detect. To overcome this problem a recent method IMS was performed. Giardia cysts were 
isolated by the method using the Dynabeads ${ }^{\circledR}$ GC-Combo IMS kit (Invitrogen Dynal AS, Oslo, Norway) according to the manufacturer's instruction.

Physico-Chemical parameters detection: A portion of each collected sample was used to test different physico-chemical parameters by laboratory expertise using standard electronic meters.

Data analysis: Data were analyzed by using Microsoft Excel and SPSS software.

\section{RESULTS AND DISCUSSION}

The present study was designed for qualitative and quantitative detection of Giardia spp. to insight into the physico-chemical parameters of the treatment plant. Total 72 raw and treated samples were collected from PSTP throughout the year (2008) and processed with Formol-Ether Concentration method and IMS followed by microscopy to identify Giardia in sewage. Microscopic observations revealed the presence of protozoan parasite Giardia in sewage water. Also, Entamoeba coli, Endolymax nana, Iodoamoeba butschlii and Balantidium coli were found (Khanum et al. 2011).

The data (Table 1) was manipulated to apply it in the population concept of parasites according to the Crofton Model which showed the variance being much greater than the mean value indicates that the distribution was aggregated or clustered. The variance in case of Measuring Chamber was greater than the mean value (Table 1). So the distribution of Giardia is also aggregated or over dispersed in measuring chamber.

Although, the interquartile range in outlet lagoon is zero, the relation between variance and mean remains the persistent as previous two sites due to a few extreme values (Table 1). From the analysis of the distribution data, it is obvious that the positive skewness increase as the treatment progresses in PSTP.

Physico-chemical parameters: The number of Giardia increased propotionally with turbidity. The lowest value of turbidity was associated with the lowest occurrence of Giardia while the highest turbidity value showed the region for the highest occurrence of Giardia in Grit Chamber. The decrease in turbidity was related to the concentration of water content. The pattern of linear relationship between turbidity and number of Giardia can be explained with scatter plot. As the other two sampling sites contained water after a series of treatment process, there might be a range of physico-chemical parameters and the occurrence of Giardia. On the contrary, the first sampling site containing the raw sewage before any treatment was done (Table 2). 


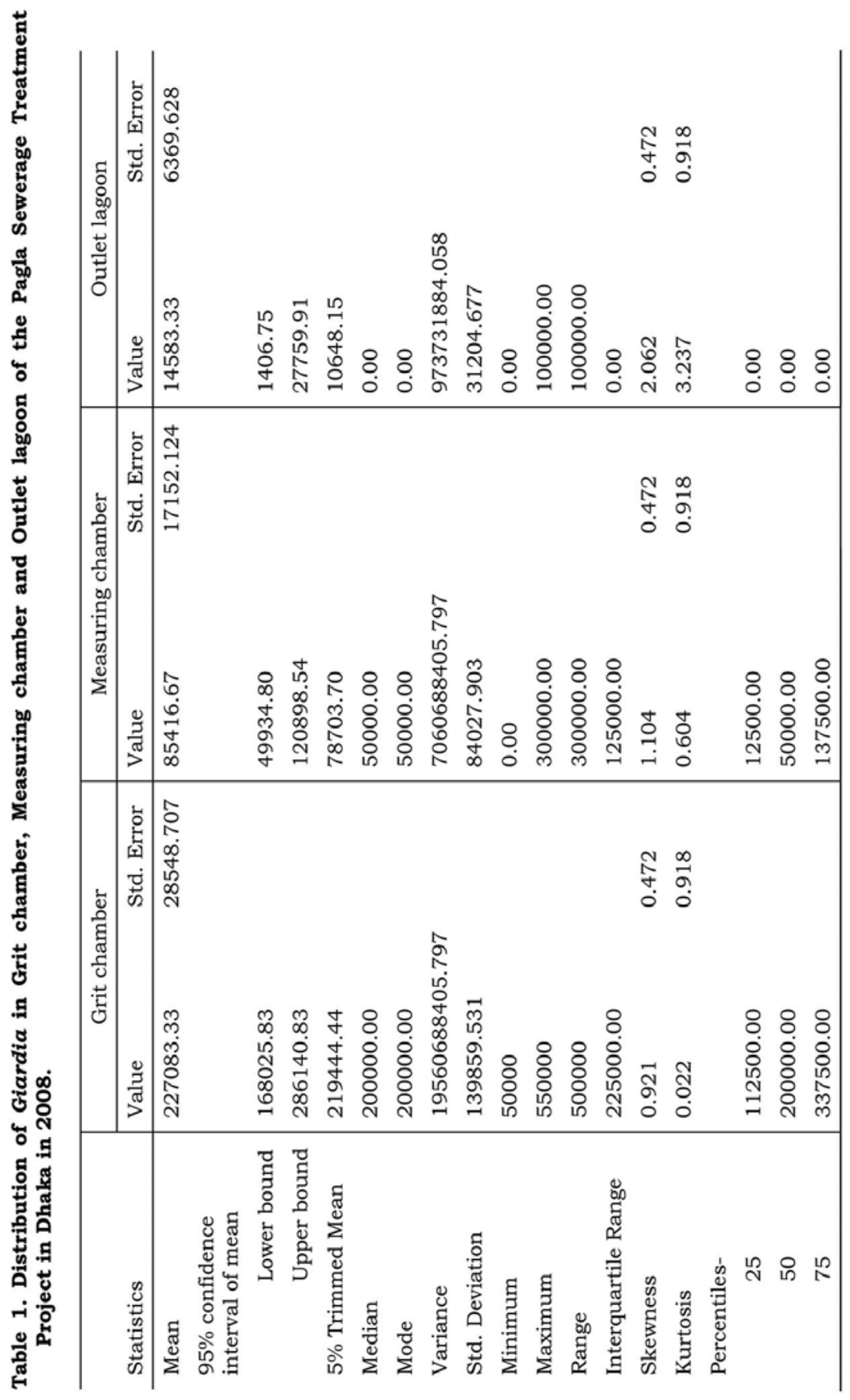




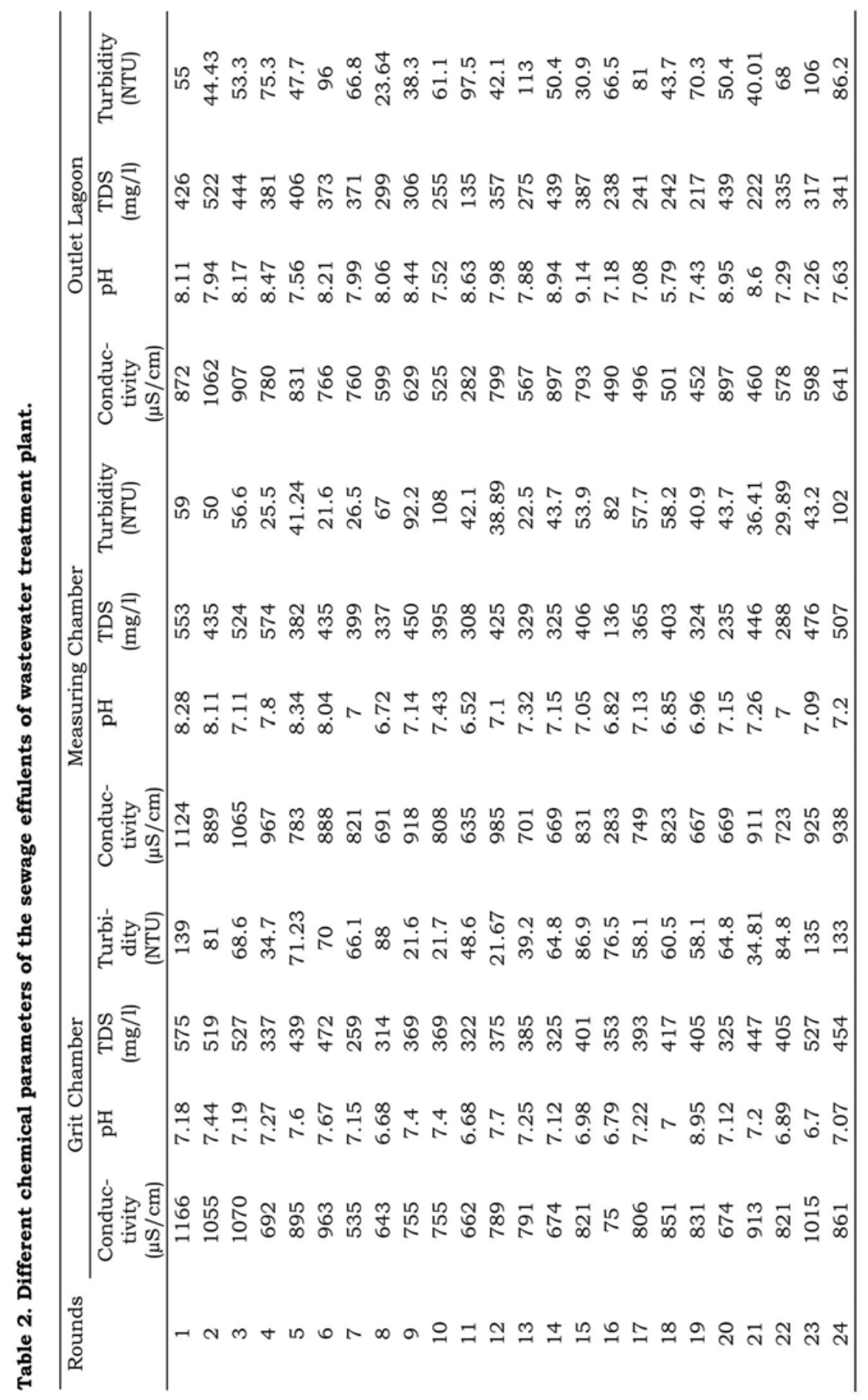


Pearson's co-efficient of correlation was used to determine the correlation between the occurrence of Giardia and the physico-chemical parameters. By Pearson's correlation analysis a distinct linear relation between the Giardia with Total Dissolved Solids (TDS) and turbidity was found in the present study (Table 3). By Pearson's bivariate correlation analysis, an effective linear correlation was found between the number of Giardia cysts in raw sewage water with turbidity ( $\mathrm{r}$ $=0.729)$ and TDS $(r=0.597)$, significant at 0.01 level. The linear relationship pointed out the fact that increasing turbidity and TDS influenced the elevation of Giardia occurrence. Although elevated turbidity may indicate an increased likelihood of parasites, water with low turbidity should not be considered without risk (Robertson et al. 2001).

Table 3. Pearson correlation between Giardia and different chemical parameters.

\begin{tabular}{lcccccc}
\hline & $\begin{array}{c}\text { Log } \\
\text { (Giardia }+1)\end{array}$ & Temperature & $\mathrm{pH}$ & Conductivity & TDS & Turbidity \\
\hline Log (Giardia +1$)$ & 1 & $-0.456\left(^{*}\right)$ & -0.052 & $0.441\left(^{*}\right)$ & $0.597(* *)$ & $0.729\left(^{* *}\right)$ \\
Temperature & $-0.456\left(^{*}\right)$ & 1 & 0.241 & -0.078 & -0.186 & -0.218 \\
pH & -0.052 & 0.241 & 1 & 0.234 & 0.114 & -0.316 \\
Conductivity & $0.441\left(^{*}\right)$ & -0.078 & 0.234 & 1 & $0.788\left(^{* *}\right)$ & 0.293 \\
TDS & $0.597\left(^{* *}\right)$ & -0.186 & 0.114 & $0.788\left(^{* *}\right)$ & 1 & $0.526\left(^{(* *}\right)$ \\
Turbidity & $0.729\left(^{* *}\right)$ & -0.218 & -0.316 & 0.293 & $0.526\left(^{* *}\right)$ & 1 \\
\hline
\end{tabular}

${ }^{*}$ Correlation is significant at the 0.05 level $\left(2\right.$-tailed) ${ }^{* *}$ Correlation is significant at the 0.01 level $(2$ tailed)

Assessment on treatment efficiency for removal of Giardia: To assess the efficiency of treatment procedure in sewage treatment plant, data were analysed using box plot. As the data covered a large range of values, a logarithmic function was used to concise the data into a more manageable range and also to overcome the biases due to the variable number of cysts and the larger differences between them as recommended by Caccio et al. (2003).

The box-plot represents a noticable difference in the distribution of Giardia in the sampling sites. The length of the box (interquartile range) increased from the first sampling point to the second one. On the contrary, the median log (number of Giardia spp. +1) decreased from the first to the second site and became the least (zero) in the third site with a few extreme values. A decrease in median indicated the efficiency of treatment procedure in the removal of Giardia (Fig. 1).

The change in box length in second site might be associated with the increasing anomaly of distribution. The box extended towards the lower quartile, which pointed out the fact that most of the observations were present in the lower quartile. The overall pattern of the box-plot revealed the tendency to lower the number of Giardia as the treatment process advances. Even though the 
median log (number of Giardia +1 ) in outlet lagoon is zero, a couple of extreme values were also found which might be the result of partial infancy of treatment procedure or secondary contamination.

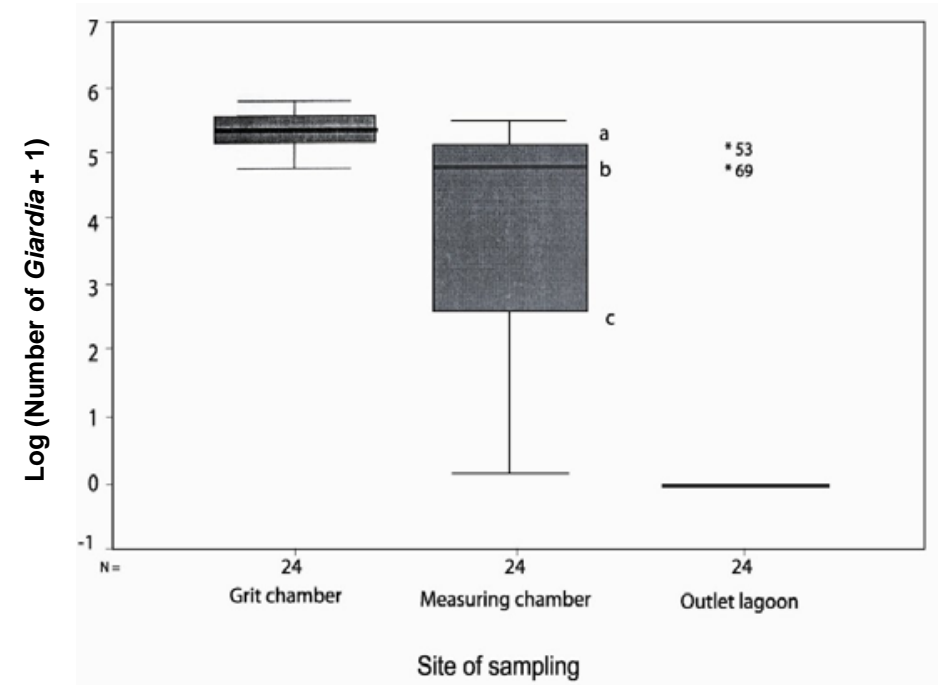

Fig. 1. Box-plot of $\log ($ Number of Cilardia +1$)$ by site of sampling $(a \rightarrow$ Upper quartile, $b \rightarrow$ Median quartile, $\mathrm{c} \rightarrow$ Lower quartile, $\mathrm{a}-\mathrm{b} \rightarrow$ Interquartile range and $* \rightarrow$ Extreme values)

An array of parasites were detected, Giardia and Entamoeba were found most frequently than others; especially $B$. coli which was found seldomly. Similar paraites were found by Lim et al. (2007) in Malaysia. Other studies conducted in Sweden, Norway and Canada also reported of constant detection of Giardia in sewage (Ottoson et al. 2006). The prevalence of Giardia was similar to Lim et al. (2007). Mean intensity, abundance and dominance were also gradually decreasing which was an indirect indication of treatment efficiency though the effulent of outlet lagoon which will be discharged into nearby waterbody does not meet the WHO 1989 criteria (Gerba and Rose 2003).

Among many other physico-chemical parameters, a very good relationship between Giardia cyst occurrence and raw water quality parameters was found in Canadian province by LeChevallier et al. (1991). The $\mathrm{pH}$ level of the water was kept for avoiding corrosion in the water reutilization system. The turbidity values contributed to assuring the removal of Giardia cysts (Bello et al. 2008). There was a positive correlation between TDS and the number of Giardia cysts found. The positive correlation between conductivity and the number of Giardia cysts in the wastewater effulents; and negative correlation with temperature in the present study was significant at 0.05 level. TDS and conductivity values 
indicate the presence of organic and inorganic nutrients for the organisms which might help Giardia cysts to servive.

The results of the present study suggest that the treatment of waste water promoted a reduction of infectious cysts of parasites when different samples from different treatment stages were compared but it could not remove those protozoan parasites properly, reflecting a constant risk of infection for the environment and the community.

\section{CONCLUSION}

Environmental protection is the original motivation for water reuse, with technologies developed for the safe reintroduction of treated waste water into the environment. To protect the surface water from pollution and contamination effective treatment and management of wastewater is a must. The reuse of recycled waste water could become an important water management option both to shore up conventional resources and to reduce the environmental impact of discharges. From the present study a better understanding of the influence of physico-chemical parameters on the treatment efficiency of PSTP was obtained. As the treated water from PSTP is directly discharged into Buriganga River which embanks Dhaka city, it's very important.

\section{LITERATURE CITED}

AMAHMID, O., ASMAMA, S. and BOUHOUM, K. 2002. Urban wastewater treatment in stabilization ponds: occurrence and removal of pathogens. Urban Water 4: 255-262.

AlMEIDA, A., MOREIRA, M.J., SOARES, S., DELGADO, M.L., FIGUEIREDO, J., SILVA, E., CASTRO, A. and COSA, J. M. C. 2010. Presence of Cryptosporidium spp. and Giardia duodenalis in Drinking Water Samples in the North of Portugal. Korean J. Parasitol. 48(1): 91-5.

BELLO, A.R.C., ANGELIS, D.F. and DOMINGOS, R.N. 2008. Microbiological and Physicochemical Treatments Applied to Metallurgic Industry Aiming Water Reuse. Braz. arch. biol. technol. 51(2): 391-397.

CACCIO, S. M., DE GIACOMO, M., Aulicino, F. A. and POZIO, E. 2003. Giardia Cysts in Wastewater Treatment Plants in Italy. Appl. Environ. Microbiol. 69(6): 3393-3398.

CARMENA, D. 2010. Waterborne transmission of Cryptosporidium and Giardia: detection, surveillance and implications for public health. Current Research, Technology and Education Topics in Applied Microbiology and Microbial Biotechnology, A Mendez Vilas (Ed.). Formatex, 3-14.

ENVIRONMENTAL PROTECTION AGENCY. 1998. Giardia: human health criteria document. United States Environmental Protection Agency.

FARIAS, E.W.C., GAMBA, R.C. and PELLIZARI, V.H. 2002. Detection of Cryptosporidium spp. oocysts in raw sewage and creek water in the city of São Paulo, Brazil. Braz. J. Microbiol. 33: 41-43.

GERBA, C. P. and ROSE, J. B. 2003. International guidelines for water recycling: microbiological considerations. Wat. Sci. Tech. 3(4): 311-316. 
HASAN, M. M., AHMED, M. K., HAFIZ, F., HUSSAIN, A. M. I., PARVEEN, S. and TINNI, S. R. 2006. Heterotrophic and nitrifying bacteria in the lagoon and the receiving river Buriganga. Bangladesh. J. Microbiol. 23: 93-97.

KARANIS, P., KOURENTI, C. and SMITH, H. 2007. Waterborne transmission of protozoan parasites: A worldwide review of outbreaks and lessons learnt. J. Water Health 5(1): 1-38.

KHANUM, H., KHANUM, S., UDDIN, M. H., DHAR, R. C. and ISLAM, M. S. 2011. Detection of protozoan parasites in a wastewater treatment plant of Bangladesh. Journal of Parasitic Diseases (Submitted).

LeCHEVALLIER, M. W. and AU, K. K. 2001. Water Treatment and Pathogen Control. IWA Publishing, London, UK. 107 pp.

LIM, Y. A. L., HAFIZ, W. W. I. and NISSAPATORN, V. 2007. Reduction of Cryptosporidium and Giardia by sewage treatment processes. Tropical Biomedicine 24(1): 95-104.

LUNA-PABELlO, V.M., MAYÉN, R., OLVERA-VIASCAN, V., SAAVEDRA, J., DE BAZÚA, C. D. 1990. Ciliated protozoa as indicators of a wastewater treatment system performance. Biological Wastes 32(2): 81-90.

NIKAEEN, M., MESDAGHINIA, A.R., TEHRANI, M. J., REZAIAN, M. and VAEZI, F.2003. Sensitive Detection of Giardia Cysts by Polymerase Chain Reaction (PCR). Iranian J. Publ. Health 32(1): $15-18$.

OTTOSON, J. 2006. Comparative analysis of pathogen occurrence in wastewater-management strategies for barrier function and microbial control. TRITA-LWR Ph.D. Thesis: $1021 \mathrm{p}$.

PARVEZ, I. M., HUSSAIN, M. D. and ALI M. R. 2007. Present status of wastewater utilization in Bangladesh: A case study in Mymensingh periurban area. Agricultura Tropica Et Subtropica 40(2): 65-70.

ROACH, P.D., OLSON, M.E., WHITLEY, G. and WALLIS, P.M. 1993. Waterborne Giardia cysts and Cryptosporidium oocysts in the Yukon, Canada. Appl. Environ. Microbiol. 59: 67-73.

ROBERTSON, L. J., and B. GJERDE. 2001. Occurrence of Cryptosporidium oocysts and Giardia cysts in raw waters in Norway. Scand. J. Public Health 29: 200-207.

SCOTT, T.M., MCLAUGHLIN, M.R., HARWOOD, V.J., CHIVUKULA, V., LEVINE, A., GENNACCARO, A., LUKASIK, J., FARRAH, S.R. and ROSE, J.B. 2003. Reduction of pathogens, indicator bacteria, and alternative indicators by wastewater treatment and reclamation processes. Water Science and Technology 3: 247- 252.

SMITH, H. V. 1998. Detection of parasites in the environment. Parasitology 117: S113-S141.

SYKORA, J. L., BANCROFT, W. D., STATES, S. J., SHAPIRO, M. A., BOUlTROS, S. N., KELETI, G., TURZAI, M. and CONLEY, L. F. 1987. Giardia cysts in raw and treated sewage. In: Controlling Waterborne Giardiasis. (Editor G.S. Logsdon). Environmental Engineering Division, American Society of Civil Engineers. pp. 22-33.

WALLIS, P.M., ERLANDSEN, S.L., ISAAC-RENTON, J.L., OLSON, M.E., ROBERTSON, W.J. and VAN KEULEN, H. 1995. Prevalence of Giardia cysts and Cryptosporidium oocysts and characterization of Giardia spp. isolated from drinking water in Canada. Appl. Environ. Microbiol. 62: 2789- 2797.

WHO. 1991. Environmental health in urban development. Techincal Report Series, No. 807, World Health Organization, Geneva. 